\title{
A Study on the Phytoremediation Potential of Azolla pinnata under Laboratory Conditions
}

\author{
L.L.U. Mandakini ${ }^{*}$, N.J.G.J. Bandara ${ }^{1}$, D. Gunawardana ${ }^{2}$ \\ ${ }^{1}$ Department of Forestry and Environmental Science, University of Sri Jayewardenepura, \\ Sri Lanka \\ ${ }^{2}$ Department of Botany, University of Sri Jayewardenepura, Sri Lanka
}

Date Received: 01-12-2015_ Date Accepted: 10-06-2016

\begin{abstract}
Heavy metal contamination in aquatic environments has become one of the major environmental problems all over the world. Phytoremediation is a plant based technology that utilises special plants known as hyperaccumulators to purify heavy metal contaminated sites. Hyperaccumulators are capable of absorbing heavy metals in greater concentrations. Azolla pinnata is an aquatic macrophyte that has been earmarked for its hyperaccumulation ability. This study was conducted under laboratory conditions to assess the ability of $A$. pinnata for the removal of $\mathrm{Cr}, \mathrm{Ni}$, $\mathrm{Cd}$ and $\mathrm{Pb}$ through rhizofiltration. Under three main experiments, phytoremediation ability of this species was investigated. In the first experiment, $A$. pinnata was exposed to prepared solutions of $\mathrm{Cr}, \mathrm{Ni}$ and $\mathrm{Pb}$ of $2 \mathrm{ppm}, 4 \mathrm{ppm}, 6 \mathrm{ppm}, 8 \mathrm{ppm}$ and $10 \mathrm{ppm}$ and of $\mathrm{Cd}$ solutions of $0.5 \mathrm{ppm}, 1.0 \mathrm{ppm}$, $1.5 \mathrm{ppm}, 2.0 \mathrm{ppm}, 2.5 \mathrm{ppm}$ and $3.0 \mathrm{ppm}$ respectively. Experiments were carried out separately for $\mathrm{Cr}, \mathrm{Ni}, \mathrm{Cd}$ and $\mathrm{Pb}$ concentrations for 7 days.
\end{abstract}

Presence of $\mathrm{Cr}, \mathrm{Ni}, \mathrm{Cd}$ and $\mathrm{Pb}$ caused a maximum inhibition of $A$. pinnata growth by $47 \%$, $54 \%, 52 \%$ and $45 \%$ respectively while the highest removal percentages of $\mathrm{Cr}-98 \%$, Ni-57\%, Cd$88 \%$ and $\mathrm{Pb}-86 \%$ were recorded in $2 \mathrm{ppm}, 2 \mathrm{ppm}, 0.5 \mathrm{ppm}$ and $8 \mathrm{ppm}$ treatments respectively. The highest Bio-concentration Factor (BCF) for Cr was 1,376.67 when treated with 6 ppm, 684.95 at 4 ppm for $\mathrm{Ni}, 1,120.06$ at $0.5 \mathrm{ppm}$ for $\mathrm{Cd}$ and 1,332.53 at $8 \mathrm{ppm}$ for $\mathrm{Pb}$ respectively. At the end of the experiments toxic symptoms were observed in plants exposed to $\mathrm{Cd}$ and $\mathrm{Ni}$. The findings of this experiment revealed that $A$. pinnata is an excellent candidate for the removal of $\mathrm{Pb}$ and $\mathrm{Cr}$ even at higher concentrations and for $\mathrm{Cd}$ at lower concentrations while it is only partially efficient for $\mathrm{Ni}$ removal. The ability of $A$. pinnata to remove $\mathrm{Cr}, \mathrm{Ni}, \mathrm{Cd}$ and $\mathrm{Pb}$ from open dump site leachate was investigated in the experiment three. A. pinnata was exposed to a leachate dilution series of $5 \%$, $15 \%, 25 \%, 50 \%, 75 \%$ and $100 \%$. For all four metals, the highest removal percentages as well as the highest $\mathrm{BCF}$ s were given by the plants exposed to $5 \%$ leachate concentration. Influence of interactive effects of $\mathrm{Cr}, \mathrm{Cd}, \mathrm{Ni}$ and $\mathrm{Pb}$ on their removal capacities of $A$. pinnata and the metal selectivities were determined by the experiment two. The metal selectivity of $A$. pinnata was $\mathrm{Pb}>$ $\mathrm{Cd}>\mathrm{Cr}>\mathrm{Ni}$. A pinnata can be designated as a good phytoremediation tool for the mitigation of heavy metal pollution due to its high BCFs (over 1,000) in relation to $\mathrm{Pb}(2-10 \mathrm{ppm}), \mathrm{Cr}(2-10 \mathrm{ppm})$ and $\mathrm{Cd}(0.5-1 \mathrm{ppm})$.

Keywords: Phytoremediation, Azolla pinnata, Heavy metals, Bio Concentration Factor, Metal

"Correspondence: upekhamandakini@ gmail.com

Tel: +94715181704

ISSN 2235-9370 Print/ISSN 2235-9362 Online (C) University of Sri Jayewardenepura 


\section{Introduction}

Many aquatic environments are polluted by heavy metals due to a myriad of reasons including industrial effluents, leaching of heavy metals from soil or bedrock and agrochemical usage in contemporary agriculture. Heavy metals are metallic chemical elements with a high atomic weight and densities five times greater than water (Sood et al., 2011). Many heavy metals are essential to the life cycles of both flora and fauna but are capable of reaching toxic levels when the supply of heavy metals through natural and anthropogenic sources exceeds their demand by inherent biological systems.

Heavy metals are considered a dangerous threat to the environment due to three key criteria, i.e. persistence, bioaccumulation and toxicity. Heavy metals are non-degradable chemical residues which possess long persistence times in the environment and gradually enter food chains and accumulate within higher trophic levels, endangering both animal and human life. Therefore the mitigation or attenuation of heavy metals from polluted aquatic environments is of great importance in protecting both the environment and human health.

Heavy metals from aquatic environments can be removed by a variety of techniques which include chemical, physical and biological techniques such as precipitation, ion exchange, chemical reduction and oxidation, membrane filtration, solvent extraction, reverse osmosis and activated carbon adsorption. However, the applications of these advanced remediation strategies are limited especially in developing countries as they are not economically feasible and require high sophisticated equipment which can be expensive to acquire. Generation of secondary wastes, metal specificity and suitability only in a narrow range of concentrations, are the other major limitations of the above methods.

One technology that is widely utilised for remediation of polluted environment is phytoremediation which is based on exploiting a plant's intrinsic mechanisms to accumulate or detoxify heavy metals from the soil or from aquatic environments. Phytoremediation is a low cost green technology and has been shown to be effective in diverse aquatic systems including reservoirs and ponds. Certain plants known as hyperaccumulators are capable of absorbing heavy metals which have no importance for plant metabolic processes. These hyperaccumulating plants which possess the capacity to absorb non-essential heavy metals are suitable candidates for efficient phytoremediation. In hyperaccumulation, heavy metal pollutants are absorbed by the roots of the plants and are concentrated in the plant tissues or decomposed to less harmful forms. Plants that can absorb and tolerate high levels of heavy metals are considered as potent candidates of phytoremediation.

Floating aquatic macrophytes are defined as plants that float on the water surface with submerged roots. Many aquatic macrophytes are potential candidates of phytoremediation as they demonstrate strong capacities to absorb non-essential heavy metals and concentrate them in tissues (Salt et al, 1995). In addition, the rapid proliferation and direct contact of aquatic macrophytes with the contaminated environment facilitates the purification process and ensures the sanitation of polluted water bodies. 
Azolla pinnata is a small free-floating aquatic fern that lives in a mutual symbiosis with a cyanobacterium (Nostoc azollae), which resides within dorsal cavities of the fronds. Nostoc azollae can fix atmospheric nitrogen into ammonium ions, which are a source of nitrogen to the water fern. Subsequent decomposition of the water fern enriches the soil of paddy fields with nitrogen and due to its benefit as a nitrogen biofertilizer, A. pinnata is cultivated widely among rice cultivars to ensure that there is a constant supply of nitrogen to the soil.

In this study, the phytoremediation potential of $A$, pinnata was assessed in an ex-situ tankbased experimental system, where its phytoaccumulation capacity for four heavy metals, namely chromium $(\mathrm{Cr})$, cadmium $(\mathrm{Cd})$, nickel $(\mathrm{Ni})$ and lead $(\mathrm{Pb})$. The data generated in this study showed that $A$. pinnata is a good phytoremediation candidate for the sequestration of $\mathrm{Cr}$ and $\mathrm{Pb}$ and possesses limited capacity to be an efficient phytoremediation agent for $\mathrm{Cd}$.

\section{Materials and Methods}

\subsection{Plants acquisition and acclimatization}

A. pinnata was obtained from paddy fields at the Rice Research and Development Institute Labuduwa, Galle. Healthy mature plants were selected for the experiment and rinsed with tap water in order to remove adhering mud particles and epiphytes. In order to adapt to the experimental conditions and to obtain substantial biomass, those plants were grown in a plastic trays containing distilled water with Albert solution for 10 days in the greenhouse of Department of Forestry and Environmental Science, University of Sri Jayewardenepura.

\subsection{Preparations of stock solutions and treatment/experiment series Experiment 1}

Concentrations of heavy metals used in the experiments largely agreed with the environmentally measured values, although in certain experiments, higher treatments exceeded the environmental pollution levels.

Treatment solutions of $\mathrm{Cr}, \mathrm{Cd}, \mathrm{Ni}$ and $\mathrm{Pb}$ were prepared by diluting the respective stock solutions of 1,000 ppm concentration. A treatment series of $2 \mathrm{ppm}, 4 \mathrm{ppm}, 6 \mathrm{ppm}, 8 \mathrm{ppm}$ and 10 ppm was performed for $\mathrm{Cr}, \mathrm{Pb}$ and $\mathrm{Ni}$, while a series of $0.5 \mathrm{ppm}, 1.0 \mathrm{ppm}, 1.5 \mathrm{ppm}, 2.0 \mathrm{ppm}, 2.5$ ppm and $3.0 \mathrm{ppm}$ was used for $\mathrm{Cd}$, on par with the environmental levels of the respective heavy metals.

Experiments for all four metal ions were carried out separately in the greenhouse at an ambient temperature of $25-35^{\circ} \mathrm{C}$. Rectangular glass aquariums with the dimensions of $28 \times 15 \times 10 \mathrm{~cm}$ were used to perform the experiment. Aquariums were filled with $2 \mathrm{~L}$ of each treatment solution in triplicates and distilled water in the absence of the metal was used as the control. One gram of Albert solution was added into each aquarium to supply the nutrient requirements and $\mathrm{pH}$ of the solutions were maintained between 6.5-7.5 throughout the experiment by titration with $\mathrm{HCl}$ and $\mathrm{NaOH}$.

Healthy and matured A. pinnata plants were selected, rinsed with distilled water and blotted on filter papers to remove adherent water and $10 \mathrm{~g}$ of the water fern were laid on the surface of each aquarium. All the experiments were run for a 7 day period. Twenty milliliters water samples were 
withdrawn from each individual replicate at 12 hour intervals. Distilled water was added based on necessity, to compensate for the water loss through evaporation and transpiration.

\section{Sample analysis}

Water samples were filtered with Whatmann No.1 filter papers and analysed by Flame Atomic Absorption Spectrometer (FAAS, GBC 932 plus) for $\mathrm{Cr}, \mathrm{Ni}, \mathrm{Cd}$ and $\mathrm{Pb}$.

On the 7th day of the experiment $A$. pinnata plants in each individual replicate were harvested, rinsed with distilled water to remove any ions adhere to plant's surface and dried out by blotting on filter papers separately. Then the fresh biomass was weighed, dried for 48 hours in an oven at $80{ }^{\circ} \mathrm{C}$ and the dry weights were subsequently measured. Dried plant biomass were digested by wet digestion method according to Kalra, (1998) and analyzed by FAAS (GBC 932 plus) to determine the metal concentrations in A. pinnata tissues.

\section{Experiment 2}

The objective of this experiment was to determine the influence of the interactive/competitive effects of $\mathrm{Cr}, \mathrm{Cd}, \mathrm{Ni}$ and $\mathrm{Pb}$ on their removal capacities of each metal by $A$. pinnata.

\section{Experimental design}

The treatment solution was prepared as a mixture of all four metals. Thus, it comprised of $\mathrm{Cr}, \mathrm{Cd}, \mathrm{Ni}$ and $\mathrm{Pb}$ concentrations which gave the highest Bio Concentration Factor (BCF) values in Experiment 1.

Table 1: Initial concentrations of $\mathrm{Cr}, \mathrm{Ni}, \mathrm{Cd}$ and $\mathrm{Pb}$ in the treatment solution.

\begin{tabular}{cc}
\hline Metal & Treatment \\
& Concentrations that gave the highest BCFs in Experiment 1 $(\mathrm{ppm})$ \\
\hline $\mathrm{Cr}$ & 6.0 \\
$\mathrm{Ni}$ & 4.0 \\
$\mathrm{Cd}$ & 0.5 \\
$\mathrm{~Pb}$ & 8.0 \\
\hline
\end{tabular}

Same experimental conditions were maintained as in experiment 1. Fifty millilitres of water samples were withdrawn from each individual replicate at 24 hours intervals and on the last day of the experiment $A$. pinnata plants were harvested, weighed after rinsing with distilled water and the adherent water removed using filter papers. Sample analysis was also done in the same manner as experiment 1 .

\section{Experiment 3}

Sample collection

Leachate samples were collected from Karadiyana solid waste dumpsite which is located adjacent to the Bolgoda river. All samples were collected at the inlets of leachate collection drains around the dumpsite in order to obtain leachate with maximum contamination of heavy metals. Leachate samples were collected in polypropylene bottles and immediately transported to the greenhouse. 


\section{Experimental design}

All collected leachate samples were mixed in order to get a homogenous mixture. A concentration series of $5 \%, 15 \%, 25 \%, 50 \%, 75 \%$ and $100 \%$ were prepared by diluting the leachate and $2 \mathrm{~L}$ of each was filled into $28 \times 15 \times 10 \mathrm{~cm}$ sized rectangular glass containers in the form of triplicates. Tap water was used as the control treatment. Healthy mature A. pinnata plants were selected, rinsed with distilled water and the water removed by blotting on filter paper. Ten grams of A. pinnata was introduced to each aquarium. The experiment was run for seven days at an ambient temperature of $25-35^{\circ} \mathrm{C}$. of leachate samples were withdrawn from each individual replicate at 24 hour intervals. A. pinnata plants were harvested at the end of the experiment and fresh weights determined by removing adherent water using filter papers, following rinsing with distilled water.

\subsection{Atomic absorption spectrometry analysis}

Water samples were filtered with Whatmann No.1 filter papers and analysed by Flame Atomic Absorption Spectrometer (FAAS, GBC 932 plus) for $\mathrm{Cr}, \mathrm{Ni}, \mathrm{Cd}$ and $\mathrm{Pb}$. Dried plant biomass digested by wet digestion method according to Kalra (1998), were also analysed by FAAS (GBC 932 plus) to determine the metal concentrations in A. pinnata tissues.

For experiment 3, a portion of original leachate was analysed for $\mathrm{Cr}, \mathrm{Cd}, \mathrm{Ni}$ and $\mathrm{Pb}$ in order to determine their initial concentrations. Leachate samples withdrawn at 24 hours intervals were digested according to APHA, (1999) and analyzed by FAAS (GBC 932 plus) to determine the remaining $\mathrm{Cr}, \mathrm{Cd}, \mathrm{Ni}$ and $\mathrm{Pb}$ concentrations in leachate treatments. Plant materials were digested and analyzed in the same manner as described above.

\subsection{Measurement of fresh and dried biomass}

On the $7^{\text {th }}$ day of the experiment $A$. pinnata plants in each individual replicate were harvested, rinsed with distilled water to remove any ions adhering to plant's surface and dried out by blotting on filter papers separately. Then the fresh biomass was weighed, dried for 48 hours in an oven at $80^{\circ} \mathrm{C}$ and the dry weights subsequently measured.

\subsection{Calculations}

The following parameters were calculated using the mean values of the data obtained from the experiments.

\section{Relative growth}

The relative growth of the plants exposed to the treatment solutions were calculated using the initial fresh weights and final fresh weights of $A$. pinnata biomass as follows (Xiaomei et al., 2004).

Relative growth $=\frac{\text { Final fresh weight }}{\text { Initial fresh weight }}$ 


\section{Removal efficiency}

The removal percentage of metal ions by A. pinnata was determined by using the initial metal concentrations of the treatment and the final concentrations at the end of the experiment (Bakar et al., 2013).

Removal efficiency $=\frac{(\text { Initial metal concentration }- \text { Final metal concentration }) \times 100}{\text { Initial metal concentration }}$

Metal uptake capacity

The accumulation of metal ions in A. pinnata tissues was calculated by using the dried weights. The metal concentrations of digested biomass were calculated as follows (Bediako, 2013).

Metal uptake $(\mathrm{mg} / \mathrm{kg})=\frac{\text { Metal concentration of the dried biomass } \times \text { Total diluted volume }}{\text { Dry weight }}$

Bio Concentration Factor (Thayapara et al., 2013)

Bio Concentration factor $=\frac{\text { Metal concentration of the dried biomass }(\mathrm{mg} / \mathrm{l})}{\text { Initial concentration of the metal in the external solution }(\mathrm{mg} / \mathrm{l})}$

\section{Results}

3.1 Phytoremediation of chromium by Azolla pinnata

High removal efficiencies were observed in all treatments, with $98 \%$ (2 ppm) to $77 \%$ (10 $\mathrm{ppm}$ ) removal efficiencies detected in the tested range ( 2 to $10 \mathrm{ppm}$ ) of $\mathrm{Cr}$ concentrations. In all treatments, high BCFs of over 1000 were observed with the highest BCF (1376.67) recorded in the $6 \mathrm{ppm} \mathrm{Cr}$ treatment. The relative growth of all $\mathrm{Cr}$ treatments were comparatively reduced to the negative control with a relative growth value of 1.14 observed in $A$. pinnata plants treated with the most concentrated treatment of $\mathrm{Cr}$ (10 ppm) (Table 2).

Table 2: Mean values of removal efficiency, relative growth, uptake and bio concentration factor (BCF) of chromium by A. pinnata.

\begin{tabular}{lrrrrrr}
\hline Parameter & Control & $2 \mathrm{ppm}$ & $4 \mathrm{ppm}$ & $6 \mathrm{ppm}$ & $8 \mathrm{ppm}$ & $10 \mathrm{ppm}$ \\
\hline $\begin{array}{l}\text { Removal } \\
\text { efficiency (\%) }\end{array}$ & 0 & 98 & 93 & 96 & 80 & 77 \\
$\begin{array}{l}\text { Relative } \\
\text { growth }\end{array}$ & 2.14 & 1.94 & 1.50 & 1.53 & 1.45 & 1.14 \\
$\begin{array}{l}\text { Cr uptake } \\
\text { (mg/kg) }\end{array}$ & 13.63 & $2,158.60$ & $5,498.70$ & $8,260.01$ & $10,887.66$ & $11,229.30$ \\
BCF & - & $1,078.81$ & $1,374.67$ & $1,376.67$ & $1,360.96$ & $1,122.93$ \\
\hline
\end{tabular}




\subsection{Phytoremediation of cadmium by A. pinnata}

The highest $\mathrm{Cd}$ removal efficiencies were observed in the $0.5 \mathrm{ppm}$ and $1 \mathrm{ppm}$ treatments, where $88 \%$ and $76 \%$ removal efficiencies were recorded in the respective treatments. The calculated BCFs of the $0.5 \mathrm{ppm}$ and $1 \mathrm{ppm}$ treatments were above 1,000. In contrast, at concentrations above $1 \mathrm{ppm}$, the calculated BCFs were well below 1,000. In all treatments, there was a significant reduction in growth with only scarce growth observed after 7 days in all treatments above $0.5 \mathrm{ppm} \mathrm{Cd}$.

\subsection{Phytoremediation of nickel}

The highest Ni removal efficiency of 57.05\% was observed in the 2 ppm treatment. All BCFs of A. pinnata exposed to Ni treatments were well below 1,000. In all treatments, there was a strong growth retardation observed in A. pinnata plants, even though the $\mathrm{Ni}$ removal efficiencies were below $57 \%$ for all concentrations (2 to $10 \mathrm{ppm}$ ) of Ni tested (Table 3 ).

Table 3: Mean values of removal efficiency, relative growth, uptake and bio concentration factor of nickel by A. pinnata.

\begin{tabular}{lrrrrrr}
\hline Parameter & Control & 2 ppm & 4 ppm & 6 ppm & 8 ppm & 10 ppm \\
\hline $\begin{array}{l}\text { Removal } \\
\text { efficiency }(\%)\end{array}$ & 0 & 57 & 50 & 42 & 40 & 25 \\
$\begin{array}{l}\text { Relative } \\
\text { growth }\end{array}$ & 2.26 & 1.64 & 1.26 & 1.14 & 1.13 & 1.05 \\
$\begin{array}{l}\text { Ni uptake } \\
\text { (mg/kg) }\end{array}$ & 0 & $1,095.84$ & $2,739.79$ & $3,173.48$ & $3,567.91$ & $4,366.93$ \\
BCF & - & 547.92 & 684.95 & 528.91 & 445.99 & 436.69 \\
\hline
\end{tabular}

\subsection{Phytoremediation of lead by A. pinnata}

The highest removal efficiency of $\mathrm{Pb}(86 \%)$ was observed in the $8 \mathrm{ppm}$ treatments. The highest $\mathrm{Pb}$ accumulation of $10,660.22 \mathrm{mg} / \mathrm{kg}$ of dry weights of plants was shown in A. pinnata plants exposed to $8 \mathrm{ppm}$ treatment. Bio concentration factors of $A$. pinnata exposed to $\mathrm{Pb}$ treatments of 4, 6 and $8 \mathrm{ppm}$, exceeded 1000, where respective BCFs of 1,158.51, 1,113.29 and 1,332.53 were calculated (Table 4).

Table 4: Mean values of removal efficiency, relative growth, uptake and bio concentration factor (BCF) of lead by A. pinnata.

\begin{tabular}{lrrrrrr}
\hline Parameter & Control & $2 \mathrm{ppm}$ & $4 \mathrm{ppm}$ & $6 \mathrm{ppm}$ & $8 \mathrm{ppm}$ & $10 \mathrm{ppm}$ \\
\hline $\begin{array}{l}\text { Removal } \\
\text { efficiency }(\%)\end{array}$ & - & 79 & 81 & 85 & 86 & 76 \\
$\begin{array}{l}\text { Relative } \\
\text { growth }\end{array}$ & 2.81 & 2.40 & 2.37 & 2.13 & 2.02 & 1.54 \\
$\begin{array}{l}\text { Pb uptake } \\
(\mathrm{mg} / \mathrm{kg})\end{array}$ & 6.29 & $1,875.31$ & $4,634.03$ & $6,679.72$ & $10,660.22$ & $9,824.71$ \\
$\mathrm{BCF}$ & & 937.65 & $1,158.51$ & $1,113.29$ & $1,332.53$ & 982.47 \\
\hline
\end{tabular}




\subsection{Phytoremediation of each heavy metal ion in a collective pool of each other}

A treatment of all four heavy metal ions was formulated by collectively pooling each heavy metal ion at the concentration at which the highest BCF was reported in each of our individual experiments. The concentration of each heavy metal ion that was used for this collective treatment is as follows; $\mathrm{Cr}-6 \mathrm{ppm}, \mathrm{Cd}-0.5 \mathrm{ppm}, \mathrm{Ni}-4 \mathrm{ppm}$ and $\mathrm{Pb}-8 \mathrm{ppm}$.

Table 5: Relative growth, removal efficiency, metal uptake and BCFs of A. pinnata for $\mathrm{Cr}, \mathrm{Ni}, \mathrm{Cd}$ and $\mathrm{Pb}$ in a collective pool of each other. The initial concentrations of each metal in the collective treatment are provided in the table below.

\begin{tabular}{cccr}
\hline \multicolumn{3}{c}{ Removal percentage (\%) } \\
$\begin{array}{c}\text { Heavy } \\
\text { metal }\end{array}$ & $\begin{array}{c}\text { Initial } \\
\text { con. }\end{array}$ & Final con. & \multicolumn{2}{c}{$\begin{array}{c}\text { Removal } \\
\%\end{array}$} \\
\hline $\mathrm{Cr}$ & 6 & 1.15 & 81 \\
$\mathrm{Ni}$ & 4 & 1.78 & 56 \\
$\mathrm{Cd}$ & 0.5 & 0.09 & 83 \\
$\mathrm{~Pb}$ & 8 & 1.20 & 85 \\
\hline Relative growth & & 1.39 \\
\hline \multicolumn{2}{c}{} & & Uptake capacity $(\mathrm{mg} / \mathrm{kg})$ \\
\hline $\mathrm{Cr}$ & & 6142.64 \\
$\mathrm{Ni}$ & & & 2719.87 \\
$\mathrm{Cd}$ & & & 524.19 \\
$\mathrm{~Pb}$ & & & 7518.18 \\
\hline & & $\mathrm{BCF}$ \\
\hline $\mathrm{Cr}$ & & 1023.77 \\
$\mathrm{Ni}$ & & 679.97 \\
$\mathrm{Cd}$ & & 1048.39 \\
$\mathrm{~Pb}$ & & 939.77 \\
\hline
\end{tabular}

Our results demonstrate that in the collective pool of heavy metal ions, $\mathrm{Cr}(6 \mathrm{ppm})$ and $\mathrm{Cd}$ $(0.5 \mathrm{ppm})$ were sequestered efficiently as reported by their high BCF factors. However, A. pinnata showed a significant decline in the phytoremediation potential of $\mathrm{Ni}$ in the collective presence of the four heavy metal ions and is likely weakened by competitive ions and polluters which act to perturb the growth and physiology of the A. pinnata plant. Furthermore, consistent with what was reported earlier in this study, A. pinnata was a poor candidate in the removal of Ni from heavy-metal infested reservoirs.

\subsection{Phytoremediation of industrial effluents containing heavy metals}

Since data are strongly favorable for the use of A. pinnata in the phytoremediation of $\mathrm{Cr}, \mathrm{Cd}$ and $\mathrm{Pb}$, it was important to extend the ex-situ experiments to assess the sanitisation of industrial effluents by the A. pinnata water fern. The collected leachate were serially diluted to a form a series of dilutions $(5 \%, 15 \%, 25 \%, 50 \%, 75 \%, 100 \%)$ and the dilutions were phytoremediated in triplicate using A pinnata. Our data demonstrate that up to a dilution strength of $15 \%, \mathrm{Cr}, \mathrm{Cd}$ and $\mathrm{Pb}$ are 
efficiently sanitized by A. pinnata, as indicated by the high BCF factors calculated for A. pinnata in the $5 \%$ and $15 \%$ leachates.

Table 6: Bio concentration factor of $A$. pinnata for $\mathrm{Cr}, \mathrm{Cd}, \mathrm{Ni}$ and $\mathrm{Pb}$ in different leachate concentrations.

\begin{tabular}{lrrrrrr}
\hline Metal ion & $5 \%$ & $15 \%$ & $25 \%$ & $50 \%$ & $75 \%$ & $100 \%$ \\
\hline $\mathrm{Cr}$ & 1248.51 & 1185.60 & 609.11 & 721.98 & 449.32 & 473.97 \\
$\mathrm{Cd}$ & 1199.19 & 1040.90 & 882.02 & 442.50 & 341.64 & 328.62 \\
$\mathrm{Ni}$ & 867.33 & 746.78 & 570.71 & 272.87 & 165.97 & 114.85 \\
$\mathrm{~Pb}$ & 1355.43 & 999.19 & 993.24 & 535.38 & 336.45 & 227.62 \\
\hline
\end{tabular}

\section{Discussion}

A. pinnata possesses a remarkable capacity to hyperaccumulate heavy metals from polluted water bodies (Wagnar, 1997). Ex situ research carried out by Salt et al., (1995), Bennicelli et al., (2004), Jangwattana., (2010), Sood et al., (2011), Deval et al., (2012), Moradi et al., (2013), Sufian et al., (2013), Thayapara et al., (2013) have shown the uptake and retention capacities of $A$. pinnata species to different heavy metal ions. These findings suggest at the potential and the applicability of A. pinnata species to phytoremediate heavy metal polluted water reservoirs.

The primary characteristics of macrophytes that possess strong phytoremediation capacities are their faster growth rates, higher biomass and greater adaptability to wide range of environmental conditions. The ability of the endosymbiont in A. pinnata (Nostoc azollae) to assimilate atmospheric nitrogen and to enhance the overall growth of the plant is an important attribute that is utilised to engender profuse propagation of the water fern in irrigated environments. Moreover, the free floating nature of $A$. pinnata and other macrophytes facilitates harvesting and their higher water content in fresh biomass (90-94\%), which drastically reduces in volume after drying, solves to a great degree the disposal dilemma of harvested material. The dry A. pinnata biomass can easily be transported to recycling sites for the recovery of the heavy metals (Sood, 2011). Furthermore, $A$. pinnata possesses a remarkable ability to survive in highly polluted waters with wide spectra of $\mathrm{pH}$, temperature and salinity, reflecting its suitability for phytoremediation applications.

\subsection{Phytoremediation potential of A. pinnata in environmentally-relevant ranges of heavy metals}

There are many sources of heavy metal ions to the wider environment including waterways. $\mathrm{Cr}$ is primarily generated through disposed batteries, anodizing and other metal finishing operations, tannery, paint and textile industries while $\mathrm{Pb}$ is released from disposable batteries, paints, via fossil fuel combustion and through runoff from road sediments of $\mathrm{Pb}$ which pollute urban waterways. $\mathrm{Cd}$ though is largely produced by the agrochemical Triple Super Phosphate (TSP) which contains between 23.5 to $71.7 \mathrm{Cd} / \mathrm{kg}$ (Noble et al., 2014) and such release of $\mathrm{Cd}$ is thought to be the main contributory factor for the presence of the often fatal illness, CKDu, in the dry zone of Sri Lanka.

There are environmental standards determined by international bodies and local regulatory organisations that ensure that heavy metals are kept below a threshold level of contamination of 
public waterways/catchments as well as public water supply. For example, the maximum concentration of $\mathrm{Cd}$ in drinking water as enforced by WHO stands at $0.003 \mathrm{ppm}$. However, it is of strong concern that in a study undertaken by Bandara, (2003), Cd levels of 0.03-0.06 ppm were reported in water samples from several reservoirs especially in North Central Province. Therefore, although in this study we have strived to treat ex-situ reservoirs with environmentally-relevant level of the tested heavy metals, it should be noted that higher contamination levels are often encountered in pollution sites.

Our results demonstrate that environmentally-relevant $\mathrm{Cr}$ and $\mathrm{Pb}$, are easily phytoremediated up to a concentration of $10 \mathrm{ppm}$ of the treated heavy metal. The BCFs for $\mathrm{Cr}$ at all treated concentrations were above a value of 1000 and for $\mathrm{Pb}$, only the BCF values at 2 ppm and $10 \mathrm{ppm}$ were marginally lower to the threshold level (937 and $982 \mathrm{ppm}$ respectively), suggesting that for both $\mathrm{Cr}$ and $\mathrm{Pb}$, there is strong phytoremediation of the respective heavy metal ions from the treated water aquariums. In the case of $\mathrm{Cr}$, the removal percentages dropped with increased treatment concentrations which were analogous to the data reported on A. pinnata (Bennicelliet et al., 2004).

In the case of $\mathrm{Cd}$, there was sound phytoremediation at 0.5 and $1 \mathrm{ppm}$, where $\mathrm{BCF}$ values were over 1,000, but beyond this value $\mathrm{Cd}$ sequestration was hindered in particular by toxicity effects of $\mathrm{Cd}$. $\mathrm{Cd}$, which is both a residue of agrochemicals and industrial effluents has been pointed as one of the primary candidates for the etiology of CKDu and the transmission of $\mathrm{Cd}$ up the food chain is of grave danger to human health. Therefore it appears that A. pinnata is an efficient tool for the removal of low levels of $\mathrm{Cd}$ (below $1 \mathrm{ppm}$ ) from polluted water reservoirs. A separate study has also demonstrated that $A$. pinnata is a sound phytoremediation tool and a useful bio fertilizer up to a concentration of $1 \mathrm{ppm} \mathrm{Cd}$, beyond which both growth and photosynthesis was handicapped due to oxidative damage induced by superoxide radicals and hydrogen peroxide (Prasad and Freitas, 2003).

It is of significance that $\mathrm{Ni}$ was not efficiently remediated by the $A$. pinnata as indicated by the low bio-concentration factors for all treatments tested. Still, there was some removal of Ni from waterways suggesting that even Ni can by accumulated in tissues of $A$. pinnata.

\subsection{Phytoremediation by A. pinnata in collective enrichments of heavy metals}

Past studies have reported that in the presence of an array of contaminants, there can be varying consequences on the individual uptake of a heavy metal ion, due to complex formation, reactivities, decreased bioavailability, competition and inhibitory effects. It is due to such phenomena that we tested the sequestration of individual heavy metal ions, in aquariums treated with all heavy metal ions used in this study. It has been reported that one of the most critical influences on individual heavy metal uptake is the supplementary metal concentrations in the medium (Marbaniangand Chaturvedi., 2014). For example, in a study by Rofkar et al., (2014), it was demonstrated that the presence of silicon $(\mathrm{Si})$ and copper $(\mathrm{Cu})$, decreased the accumulation of arsenic (As) by Azolla caroliniana.

This experiment was designed to entertain collectively the concentrations with the highest BCFs for individual ions, as determined by the BCFs calculated for A. pinnata in a series of individual treatments for each heavy metal ion. The BCF values obtained from collective treatment 
of $\mathrm{Cr}, \mathrm{Cd}, \mathrm{Pb}$ and $\mathrm{Ni}$, demonstrated that high $\mathrm{BCF}$ values were retained for $\mathrm{Cr}(6 \mathrm{ppm})$ and for $\mathrm{Cd}$ $(0.5 \mathrm{ppm})$ even in the presence of competing ions, suggesting that there was minimal displacement of uptake of $\mathrm{Cr}$ and $\mathrm{Cd}$ by the presence of auxiliary heavy metals. On the other hand, the phytoremediation of $\mathrm{Pb}$ was marginally decreased in the presence of three other co-polluting heavy metal ions, suggesting that there may have been interactive or competitive effects that could have hindered the accumulation of lead by the A. pinnata.

\subsection{Applications of A. pinnata to industrial effluents/treated samples}

Numerous studies have demonstrated that industrial effluents can be sanitised by using plants of high phytoremediation potential. For example, in a study by Rizwana et al., (2014), the phytoremediation potential of Eicchornia crassipes, Lemna trisulca, Oenathe javanica and Lepronia articulate were identified, due to their efficient removal of $\mathrm{Cd}$ and $\mathrm{Pb}$ from textile industry effluents. However growth retardations, such as in Vetivaria zizanioides, due to the presence of $\mathrm{Mn}, \mathrm{Fe}$ and $\mathrm{Cu}$, as reported by Roontanakiat et al., 2007, are a common characteristic due to the toxic nature of heavy metal ions.

In this experiments with industrial effluents, it was observed that $\mathrm{Cr}$ and $\mathrm{Cd}$ was amenable for phytoremediation at 5\% and $15 \%$ dilutions of leachate as indicated by BCFs over 1000 for both. $\mathrm{Pb}$ too showed a high $\mathrm{BCF}$ values nearing or above 1000 for the $5 \%$ and $15 \%$ leachates demonstrating that at lower dilutions of effluents (such as following chemical or physical treatment), there is good potential for phytoremediation by A. pinnata.

It is suggested that industrial leachates which are treated initially with chemicals or filtered through membranes/adsorption surfaces, and thus diluted, are sound contenders to be phytoremediated by macrophytes such as A. pinnata. Therefore a shallow to medium-depth pondbased system where $A$. pinnata is cultivated as a surface lining can be used successfully to cleanse industrial effluents such as $\mathrm{Cr}, \mathrm{Cd}$ and $\mathrm{Pb}$ and such a system is worth an effort to exploit the potential of biological heavy metal quenchers such as $A$. pinnata to sanitize industrial residue, prior to their contamination of public waterways.

\subsection{Growth responses of A. pinnata to selective and collective heavy metals}

Growth changes are often the first and most obvious indicators of plants under heavy metal stress (Deval et al., 2012). In this study, plant growth was measured in terms of relative growth of the treated plants as compared to the corresponding negative control (in the absence of heavy metal treatment).

In the presence of $\mathrm{Cr}$ and $\mathrm{Pb}$ (between a range of 2 and $10 \mathrm{ppm}$ ), the growth of $A$. pinnata was inhibited by $9-47 \%$ and $14 \%-45 \%$ respectively compared to the corresponding controls and there was a dose-dependency of the retardation of growth to the level of treatment of the selected heavy metal. The presence of $\mathrm{Ni}(2$ to $10 \mathrm{ppm}$ ) caused a direct reduction of A. pinnata growth by $27-54 \%$ relative to the negative control even though the removal efficiencies of Ni were low at all concentrations tested.

A growth reduction of $12-52 \%$ was observed in the presence of $\mathrm{Cd}(0.5-3 \mathrm{ppm})$ relative to the negative control. A. pinnata exposed to $0.5 \mathrm{ppm}$ treatment showed the highest relative growth of 
1.95 and in all other treatments (1-3 ppm), there was no significant growth recorded, while the plants appeared to undergo chlorophyll degradation due to the decoloration of fronds. Similar observations were made by Lu et al., (2004) and Hasan et al., (2006) where the relative growth of water hyacinth plants were significantly decreased with moderately high Cd concentrations (2 and 4 ppm). Uysal and Taner (2009) also reported that high Cd concentrations created various toxicity symptoms on Lemna minor such as yellow coloration of plant leaves and decomposition of plants. In another study by Delgado et al., (1993) concerning the phytotoxic effect stemming from the uptake of $\mathrm{Cd}, \mathrm{Cr}$ and $\mathrm{Zn}$ by water hyacinths, $\mathrm{Cd}$ was identified as most toxic to the water hyacinth plants. Therefore, our results agree with past findings on the formidable toxicity of $\mathrm{Cd}$ to macrophytes and other water plants.

\section{Conclusion}

We conclude by nominating A. pinnata as a phytoremediation agent that can be used for the sanitization of selective heavy metals, namely $\mathrm{Cr}, \mathrm{Cd}$ and $\mathrm{Pb}$ and this technology offers efficient, easy, cost-effective, environmentally-sustainable solution to the problem of heavy metal accumulation in public reservoirs and waterways. It is of significance that in Sri Lanka, a fatal and debilitating condition designated as $\mathrm{CKDu}$ is fast reaching epidemic status and $\mathrm{Cd}$ which has been shown to be relevant to the etiology of this illness, requires to be extracted from contaminating sites such as irrigated rice fields, waterways and reservoirs. A. pinnata, which is abundantly used as a nitrogen-infuser for rice cultivation provides a vehicle for purifying water bodies infested with $\mathrm{Cd}$, and thus allows for the arrest of transport of $\mathrm{Cd}$ up the food chains and through water consumption and consequently will contribute towards the management of the disease and the diseased in relation to $\mathrm{CKDu}$.

It is also suggested that artificial pond-based systems cultivated with A. pinnata can easily be employed as a biological filter to quench heavy metal ions from industrial effluents and to let the resultant flow-through exit from the drainage system. Using such a filter-system will ensure that industrial pollutants are trapped, removed and destroyed prior to their contamination of public water bodies. The easily harvestable nature of $A$. pinnata is of significant benefit both in industrial ponds and in rice fields where pollution from effluent discharge and agrochemical usage is of major concern. The use of mechanical or manual harvesting can easily be performed and the heavy-metal enriched water ferns can be used for the chemical extraction of heavy metals such as $\mathrm{Cr}$ and $\mathrm{Pb}$, which have numerous applications once recycled. Therefore, A. pinnata, although not a panacea for heavy metal contamination, offers a feasible solution to remediate polluted water bodies by the entrapment of selective heavy metals within the biological tissues of this miniature green wonder.

\section{References}

APHA 1999. Standard method for examination of water and waste water. American Public Health Association, American Water Works Association and Water Environment Federation.

Bakar, A.F.A., Yusoff, I., Fatt, N.T., Othman, F. and Ashraf, M.A. 2013. Arsenic, zinc, and aluminium removal from gold mine wastewater effluents and accumulation by submerged aquatic plants (Cabomba piauhyensis, Egeria densa, and Hydrilla verticillata). BioMed Research International, http://dx.doi.org/10.1155/2013/890803.

Bandara, N.I.G.J., 2003. Water and wastewater issues in Sri Lanka. Water Science \& Technology, 47: 305-312. 
Bediako, E.O., 2013. Potentials of Adiantum raddianum and Nephrolepis exaltata for phytoextraction of heavy metals in spiked soils. M. Sc. Thesis, Department of Environmental Science, Kwame Nkrumah University of Science and Technology, Ghana.

Bennicelli, R., Stezpniewska, Z., Banach, A., Szajnocha, K. and Ostrowski, J. 2004. The ability of Azolla caroliniana to remove heavy metals ( $\mathrm{Hg}(\mathrm{II}), \mathrm{Cr}(\mathrm{III}), \mathrm{Cr}(\mathrm{VI})$ ) from municipal waste water. Chemosphere, 55: 141-146.

Delgado, M., Bigeriego, M., Guardiola, E. 1993. Uptake of Zn, Cr and Cd by Water Hyacinth, Water Research, Elsevier, 27(2): 269-272.

Deval, C. G., Mane, A. V., Joshi, N. P. and Saratale, G. D. 2012. Phytoremediation potential of aquatic macrophyte Azolla Caroliniana with references to zinc plating effluent. Emir. Journal of Food Agriculture, 24(3): 208-223.

Hasan, S.H., Talat, M. and Rai, S. 2006. Sorption of cadmium and zinc from aqueous solutions by Water Hyacinth (Eichchorniacrassipes). Bioresource Technology, Science Direct, 98: 918928.

Jangwattana, R. 2010. Using Azolla pinnata for waste water treatment from poultry farm. International Journal of Environmental and Rural Development, 1(2).

Kalra, Y.P. 1998. Handbook of reference methods for plant analysis. Soil and Plant Analysis Council, CRC Press, Taylor \& Francis Group.

Lu, X., Kruatrachue, M., Pokethitiyook, P.and Homyok, K. 2004. Removal of cadmium and zinc by Water Hyacinth, Eichhornia crassipes. Science Asia, 30: 93-103.

Marbaniang, D., and Chaturvedi, S.S. 2014. Assessment on $\mathrm{Cr}, \mathrm{Cd}$, $\mathrm{As}, \mathrm{Ni}$ and $\mathrm{Pb}$ uptake and phytoremediation potential of Scirpus mucronatus, International Journal of scientific research \& management, 2(6): 965-969.

Moradi, S., Yosefi, R. and Ghaderi, O. 2013. Bioconcentration factor and relative growth rate of Azolla (Azolla caroliniana) in arsenic and salinity stress conditions. International Journal of Agronomy \& Plant Production, 4 (10).

Noble, A.; Amerasinghe, P.; Manthrithilake, H.; Arasalingam, S. 2014. Review of literature on chronic kidney disease of unknown etiology (CKDu) in Sri Lanka. Colombo, Sri Lanka: International Water Management Institute (IWMI), 41p. (IWMI Working Paper 158), DOI: 10.5337/2014.206.

Prasad, M.N.V. and Freitas, H.M. 2003. Metal hyperaccumulation in plants-biodiversity prospecting for phytoremediation technology. Electronic Journal of Biotechnology, 6(3).

Rizwana, M., Darshan, M. and Nilesh, D. 2014. Phytoremediation of textile waste water using potential wetland plant: Eco sustainable approach. International Journal of Interdisciplinary \& Multidisciplinary Studies, 1(4): 130-138.

Rofkar, J.R., Dwyer, D.F. and Bobak, D.M. 2014. Uptake and toxicity of arsenic, copper, and silicon in Azolla caroliniana and Lemna minor. International Journal of Phytoremediation, 16(2): 155-166, DOI: 10.1080/15226514.2012.759534.

Roongtanakiat, N., Tangruangkiat, S. and Meesat, R. 2007. Utilization of vetiver grass (Vetiveria zizanioides) for removal of heavy metals from industrial wastewaters. Science Asia, 33: 397403.

Salt, D.E., Blaylock, M., Kumar, N.P.B.A., Dushenkove, V., Ensley, B.D., Chet, I., Raskin, I., 1995. Phytoremediation: A novel strategy for the removal of toxic metals from the environment using plants. Biotechnology, 13. 
Sood, A., Uniyal, P.L., Prasanna, R. and Ahluwalia, A.S. 2011. Phytoremediation potential of aquatic macrophyte, Azolla, Royal Swedish Academy of Sciences, Springer, 41: 122-137. [Online] DOI 10.1007/s13280-011-0159-z.

Sufian, J., Golchin, A., Avanes, A. and Moradi, S. 2013. Potentials of Azolla (Azollam caroliniana) for uptake of arsenic from contaminated waters with different levels of salinity. International Journal of Agriculture and Crop Sciences, 6(12): 778-783.

Thayapara, M., Iqbal, S.S., Chathuranga, P.K.D. and Iqbal, M.C.M. 2013. Rhizofiltration of Pb by Azolla pinnata. International Journal of Environmental Sciences, 3(6), DOI:10.6088/ijes.2013030600002.

Uysal, Y. and Taner, F. 2009. Effect of pH, temperature, and lead concentration on the bioremoval of lead from water using Lemna minor, International Journal of Phytoremediation, 11(7): 591-608, DOI: 10.1080/15226510902717648.

Wagnar, G.M. 1997. Azolla: A review on its biology and utilization. Botanical Reviews, 63: 1-26.

Xiaomei, L., Maleeya, K., Prayad, P. and Kunaporn, H. 2004. Removal of cadmium and zinc by Water Hyacinth, Eichhornia crassipes. ScienceAsia, 30: 93-10. 